\title{
What Enables Effective International Climate Finance in the Context of Development Co-operation?
}

Sáni Ye Zou and Stephanie Ockenden

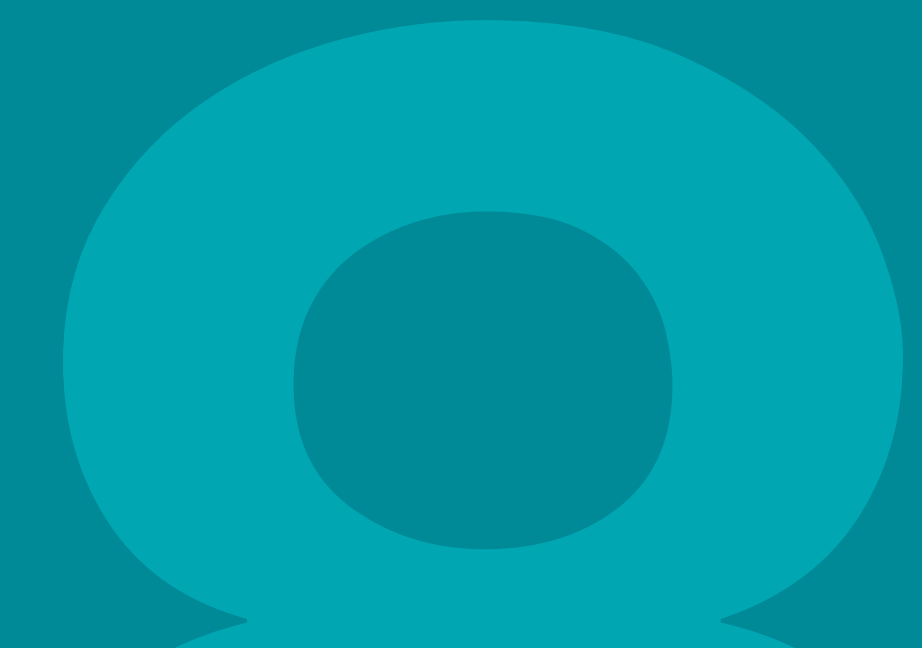

OECD DEVELOPMENT CO-OPERATION WORKING PAPER 28

Authorised for publication by Brenda Killen, Deputy Director, Development Co-operation Directorate 


\section{OECD Development Co-operation Working Papers}

OECD Working Papers should not be reported as representing the official views of the OECD or of its member countries. The opinions expressed and arguments employed are those of the authors.

Working Papers describe preliminary results or research in progress by the author(s) and are published to stimulate discussion on a broad range of issues on which the OECD works. Comments on the present Working Paper are welcomed and may be sent to DAC.Contact@oecd.org or the Development Co-operation Directorate, OECD, 2 rue AndréPascal, 75775 Paris Cedex 16, France.

This document and any map included herein are without prejudice to the status of or sovereignty over any territory, to the delimitation of international frontiers and boundaries and to the name of any territory, city or area.

You can copy, download or print OECD content for your own use, and you can include excerpts from OECD publications, databases and multimedia products in your own documents, presentations, blogs, websites and teaching materials, provided that suitable acknowledgement of OECD as source and copyright owner is given. All requests for public or commercial use and translation rights should be submitted to rights@oecd.org. 


\title{
WHAT ENABLES EFFECTIVE INTERNATIONAL CLIMATE FINANCE IN THE CONTEXT OF DEVELOPMENT CO-OPERATION?
}

Sáni Ye Zou and Stephanie Ockenden

\begin{abstract}
In response to on-going discussions on the relationship between international climate finance and development finance, this paper explores what enables effective international climate finance in the context of development co-operation. Through interviews, views were elicited from selected international climate finance stakeholders representing climate finance recipient and provider countries, as well as experts from international organisations and research institutions. Identified enabling conditions reveal common grounds and differences across stakeholder groups. This offers a possible starting point for further dialogue aiming to advance the international climate and development finance agendas in a harmonised manner.
\end{abstract}

Keywords: climate finance, effectiveness, development co-operation, mainstreaming, national planning 


\section{ACKNOWLEDGEMENTS}

This paper was authored by Sáni Ye Zou and Stephanie Ockenden. The authors would like to thank Jan Corfee-Morlot, Sara Fyson, Raundi Halvorson-Quevedo, Nicolina Lamhauge and Suzanne Steensen from the Development Co-operation Directorate, and Jane Ellis and Randy Caruso from the Environment Directorate of the Organisation for Economic Co-operation and Development (OECD) for their comments on earlier drafts and help in carrying out this work. The authors would also like to thank all interview respondents for their insights and time dedicated to this research, many of whom also provided valuable comments on earlier drafts of the paper. 
TABLE OF CONTENTS

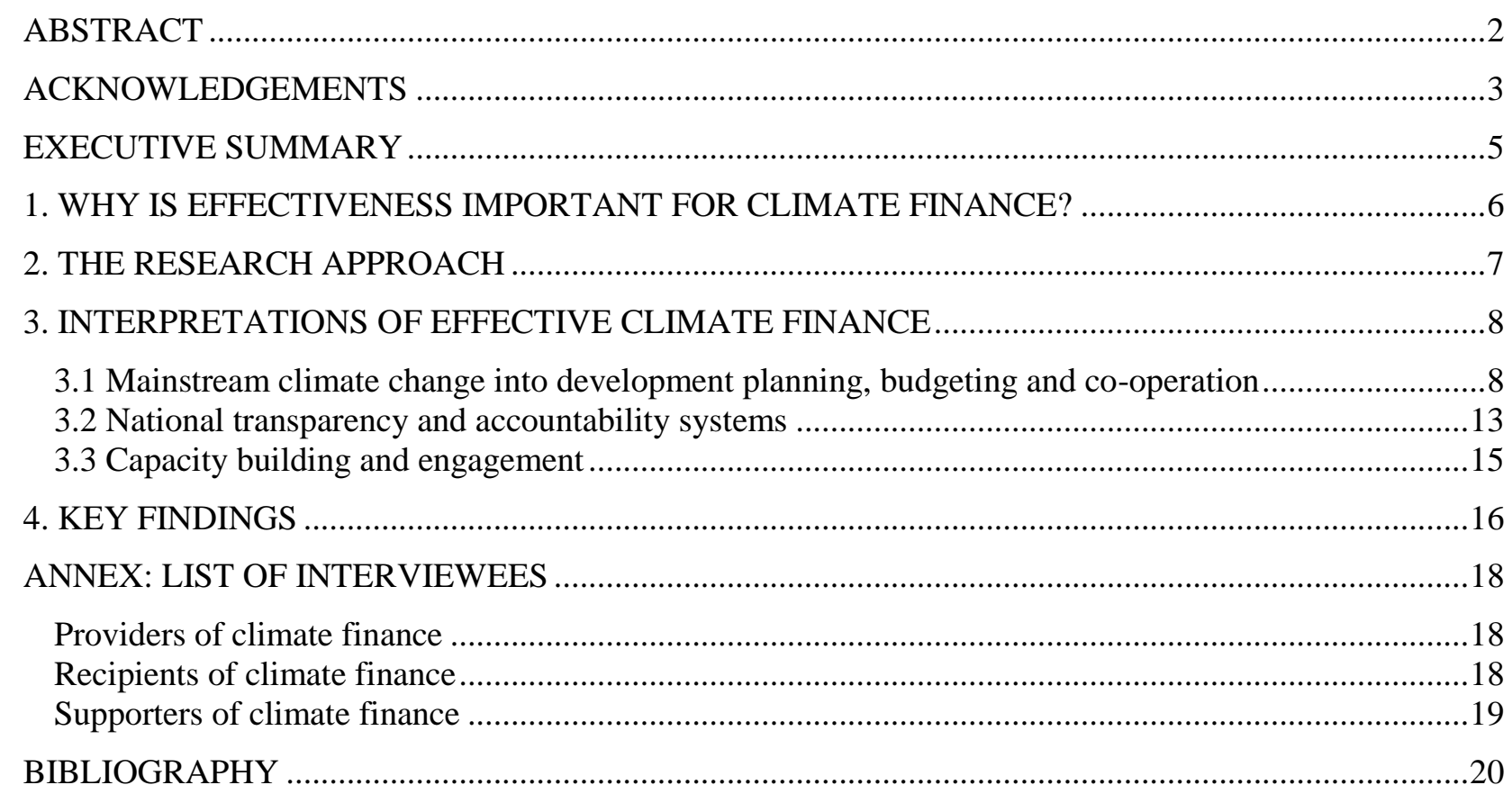

\section{Tables}

Table 1. Pre-condition according to respondent groups, areas of convergence and divergence ...........8

\section{Boxes}

Box 1. Mechanisms for development co-operation on climate finance in partner countries .11 


\section{EXECUTIVE SUMMARY}

Growing recognition of the urgency to act on climate change and the importance of financing underscore the need to understand and achieve effectiveness. This report explores current understanding of what makes international climate finance effective - focusing on climate-related development finance. Its scope includes, but is not limited to, official development assistance (ODA). The research approach used is qualitative, and is based on a series of in-depth interviews. Interpretations and views were elicited from a sample of twenty-six different stakeholders or stakeholder groups, representing countries both receiving and providing climate finance (referred to as "recipients" and "providers" respectively) as well as international organisations and research institutions (referred to as "supporters"). The emerging insights from the research highlight similarities and differences in views around the key pre-conditions for effectiveness. Informed by the interviews, the following key findings emerge:

- The international climate finance community is widely aware of the Paris-Accra-Busan aid effectiveness principles and agree that these principles apply, where appropriate, to the effective delivery of climate-related development finance.

- Recipients, providers and supporters have shared views and recognition for important preconditions of effective climate finance. These include: mainstreaming climate change into development planning and policies; co-ordination and clear allocation of responsibilities, tracking and monitoring systems for climate finance in recipient countries; readiness and ease of access to climate funds; and the engagement of civil society, local government and the private sector.

- Views and experiences vary across stakeholders and countries on the use of country systems and the role of national climate funds - highlighting how pre-conditions can be context specific and can vary according to sources and objectives of finance.

- The results revealed that all groups seek to establish robust and credible transparency systems as a pre-condition for good outcomes. Providers highlighted the importance of monitoring and evaluating the results associated with finance flows, while recipients prioritised building systems for tracking the finance flows.

- To deliver international finance more effectively, national level actors have a key role to play in setting the agenda and in bringing different communities together; while development cooperation providers can, to the extent possible, contribute towards enhanced co-ordinating with each other in the countries in which they operate.

- Going forward, a broader set of pre-conditions may be required for effective international climate finance, given the increasing role of private climate finance, South-South and triangular co-operation, as well as domestic enabling environments to shift and mobilise investments consistently with low-carbon, climate resilient development. 


\section{WHY IS EFFECTIVENESS IMPORTANT FOR CLIMATE FINANCE?}

1. Under the United Nations Framework Convention on Climate Change (UNFCCC), developed countries committed in 2009 to jointly mobilise USD 100 billion of climate finance to developing countries annually by 2020 . The new 2015 Paris Agreement continues this collective mobilisation goal through to 2025 in the context of meaningful mitigation actions and transparency on implementation. These expected finance flows are of similar magnitude to the current level of net official development assistance (ODA), which was USD 135 billion $^{1}$ in 2014, and climate-related ODA is one of the main sources of climate finance reported to date $(\mathrm{OECD}, 2016)$. Climate finance was also on the agenda of development finance negotiations in $2015^{2}$, emphasising a growing priority to better understand and manage the co-benefits and trade-offs between financing for sustainable development and climate change. The growing recognition of the urgency to act on climate change and the importance of financing for development heighten the need to ensure that finance is effectively allocated, disbursed and delivered.

2. This paper, and the underpinning qualitative research upon which the findings rest, explores the question "what enables effective international climate finance in the context of development cooperation?" The focus is not about results or outcomes per se, but about the overall objectives and preconditions to effective climate finance that can be considered at different stages from the design to delivery of finance, at the international and national levels, as well as for programme and project-level activities. Through the use of semi-structured interview techniques across a sampling of diverse stakeholders in the climate finance arena, the authors consider perceptions about the relative importance and relevance of different principles and pre-conditions for success, to understand what supports effective climate finance outcomes.

3. To date, there is not a commonly agreed definition of what constitutes "effective" climate finance. The OECD Development Assistance Committee (DAC) defines effectiveness in the context of development co-operation as "the extent to which the development intervention's objectives were achieved, or are expected to be achieved" (OECD, 2010a). However, there is no common set of widely accepted criteria against which effectiveness can be measured and upon which to form an understanding of what constitutes as "effective international climate finance" (Ellis, Caruso and Ockenden, 2013; Brown et al., 2011). Reaching a common view is inherently difficult, due to the number of providers and range of channels operating across the climate and development finance communities; the diversity of recipient countries each with different needs, priorities and development agendas; and an increasing selection of instruments used to mobilise climate finance (e.g. grants, loans, export credits and guarantees). However, bringing together a variety of different stakeholders' views and experiences on how to effectively manage international climate finance can help to identify points of common interest and agreement, where further discussion is needed and where best practices can be identified and shared across countries and communities of practice.

4. A key benchmark for climate finance is the commitment taken by developed countries under the UNFCCC to mobilise USD 100 billion in support for developing countries to act on climate change. The USD 100 billion climate finance goal is to be mobilised from a range of sources, public and private, bilateral and multilateral ${ }^{3}$. The role of international public finance, as well as other international development co-operation actions, is however significant, and expected to remain so. For 2013 and 2014, the annual average climate finance is estimated to be USD 57 billion, of which over 70\% (USD 41 billion) is estimated to be public finance, either bilateral and multilateral (OECD, 2016). It is also evident that not all climate-related development finance is reported as climate finance to the UNFCCC, and that these 
flows may be broader (OECD, 2016). Bilateral climate-related ODA commitments, as reported by donors to the OECD DAC, have been on an increasing trend since 2007, and reached USD 25 billion on average per year in 2013-14; multilateral public climate finance reached USD 25 billion on average per year (OECD, 2015).

5. Aid effectiveness principles can provide a useful starting point for considering how to effectively deliver and use international climate finance. Fifty years of development co-operation practice have yielded lessons on effective aid ${ }^{4}$, summarised in the principles of ownership, alignment, harmonisation, results and mutual accountability, which are supported and referred to as best practice across the development co-operation community. In the Busan Fourth High-Level Forum on Aid Effectiveness (2011), climate finance was formally recognised as a core development finance issue, with the common goal to "support national climate change policy and planning as an integral part of developing countries overall national development plans, and ensure that - where appropriate - these measures are financed, delivered and monitored through developing countries' systems in a transparent manner" ${ }^{\prime \prime}$. There are cobenefits and trade-offs in financing sustainable development and climate change goals simultaneously.

6. Beyond international public finance, a significant and increasing amount of international climate finance is expected to be mobilised from the private sector. South-South and triangular co-operation is also expected to increase. The effectiveness (as well as the definition) of international climate finance may therefore rely on a broader set of conditions than those defined for aid or public finance more generally. The scope of this paper focuses on public international climate finance to developing countries, but also considers developed country finance and policies used to mobilise private investments at home and abroad. Furthermore, while the paper recognises that domestic finance also has an important role in financing adaptation and mitigation (CPI, 2014), it is beyond the scope of this paper.

\section{THE RESEARCH APPROACH}

7. This study gathers and brings together views from international development co-operation and climate change policy communities. It explores views on the question "What are the conditions of effective international public climate finance?" in the context of the mandate and practices of each respondent. This paper does not seek to draw conclusions. Rather, it draws on examples of current practice to identify barriers, challenges and emerging lessons, and presents opportunities highlighted by practitioners and experts where development co-operation can play a role in improving the effectiveness of international public climate finance.

8. The research was conducted by interviewing twenty-six climate finance specialists and stakeholders using a pre-defined set of questions and semi-structured interview techniques. The interviews were conducted over the phone and in person. The individuals participating in the interviews represented seven governments and a non-governmental organisation (NGO) in recipient countries of international climate finance, nine climate finance providers from bilateral donor agencies and multilateral development banks, and nine international organisations and research institutes categorised for the purpose of this paper as "supporters" of climate finance. This subset of practitioners and researchers working on international climate finance has been selected to represent views from developed and developing countries, with the aim to provide initial insights, as a starting point for further discussion. 


\section{INTERPRETATIONS OF EFFECTIVE CLIMATE FINANCE}

9. Based on a synthesis of responses, three categories of pre-conditions for effectiveness emerged from the interviews. By and large, these categories suggest multiple linkages between the enabling conditions for effective international climate finance and the Paris-Accra-Busan aid effectiveness principles. Table 1 summarises the findings, identifying where there is a common understanding for each pre-condition within and across the three respondent groups, as well as areas of divergence of views and priorities.

Table 1. Pre-condition according to respondent groups, areas of convergence and divergence

Areas of consensus

Partial consensus / different emphasis on priorities

Areas of divergence

\begin{tabular}{|c|c|c|c|}
\hline Pre-conditions for effectiveness & Recipients & Providers & Supporters \\
\hline \multicolumn{4}{|c|}{ 1. Mainstream climate change into development planning, budgeting and co-operation } \\
\hline \multicolumn{4}{|l|}{$\begin{array}{l}\text { A. Integrate climate change into national development plans and } \\
\text { budgets }\end{array}$} \\
\hline \multicolumn{4}{|l|}{$\begin{array}{l}\text { B. Institutional co-ordination across ministries and international finance } \\
\text { providers }\end{array}$} \\
\hline \multicolumn{4}{|l|}{$\begin{array}{l}\text { C. Mainstream climate change considerations into development co- } \\
\text { operation }\end{array}$} \\
\hline \multicolumn{4}{|l|}{$\begin{array}{l}\text { D. Align international climate finance with national strategies and } \\
\text { priorities }\end{array}$} \\
\hline \multicolumn{4}{|l|}{$\begin{array}{l}\text { E. Use of country systems to channel international climate finance } \\
\text { (where appropriate) }\end{array}$} \\
\hline \multicolumn{4}{|l|}{ 2. National transparency and accountability systems } \\
\hline \multicolumn{4}{|l|}{ F. Systems for tracking finance } \\
\hline \multicolumn{4}{|l|}{ G. Systems for monitoring results and impacts } \\
\hline \multicolumn{4}{|l|}{ 3. Capacity building and engagement } \\
\hline \multicolumn{4}{|l|}{ H. Access and readiness to finance from international climate funds } \\
\hline I. Engagement with civil society, local government and the private sector & & & \\
\hline
\end{tabular}

Note: The table summarises areas of convergence and divergence within each respondent group.

\subsection{Mainstream climate change into development planning, budgeting and co-operation}

10. It is recognised by all recipients, providers and supporters that climate change is not an isolated or "niche" policy area, and that climate finance can be most effective in contexts where climate change is treated within national development plans as a cross-cutting issue of sustainable development. Lowcarbon, climate resilient development strategies have been found to support an integrated national approach to climate change planning and economic development (Clapp et.al, 2010; OECD, 2010b, 2013, 2014). 


\section{A. Integrating climate change into national development plans and budgets}

11. According to all respondent groups, mainstreaming climate change into development planning in recipient countries is an important pre-condition for effective climate finance. One reason for this is that it is important for the core government ministries responsible for national planning and budgeting to acknowledge the contribution of climate smart and resilient activities towards mid- and long-term development goals, and mainstream climate actions and finance into the decision-making of sectoral ministries, departments and agencies.

12. Indeed, recipients found that developing national climate change plans and a strategic vision and systematic response to climate change across government encourages providers to channel external funding through country-owned systems, thereby responding to national priorities. Providers also noted that this was a vital pre-condition for channelling climate finance through budget support. In contrast, the absence of an integrated national vision on climate change was reported as a contributing factor towards providers' decisions to finance their own priorities. Interestingly, this was reported to still be the case in instances where national climate change policy papers exist i.e. NAMAs or NAPAs ${ }^{6}$, suggesting that centralised consideration of climate change priorities are more important than standalone climate change plans, although the latter can be a first step in formulating national priorities. Some countries, such as Kenya and Indonesia, have already started to integrate strategic priorities on climate change into their medium-term national development plans.

13. The majority of recipients and supporters, and some providers interviewed highlight that identifying priority sectors for national climate change action is a pre-condition for effectiveness. It was further explained that taking a bottom-up approach towards the formulation of national climate change strategies allows for sector specific planning and financing needs to be taken into account. There is a range of examples on how this is being done on a country-by-country basis. The experience of respondents from recipient countries' reflected that the national context in which climate change priorities are considered can vary greatly across countries. For example, the Colombian national development strategy mainstreams climate change priorities through four sectoral public policy areas ${ }^{7}$; while in Kenya a stand-alone climate change action plan identifies six 'big win' opportunities ${ }^{8}$ for climate finance with adaptation and mitigation co-benefits (Government of Kenya, 2012). In response to lessons learned on what might strengthen the effectiveness of climate finance, supporters and providers have been providing technical assistance to help identify climate-related sectors in the national context, and to developing cross-sectoral national climate change strategies and action plans.

\section{B. Institutional co-ordination across ministries and international finance providers}

\section{Recipients allocate roles and responsibilities across ministries and monitor action}

14. Recipients, providers and supporters equally recognise that a co-ordinated national response to climate change and national policy coherence are pre-conditions for effective decision-making over climate finance. According to recipients, intra-governmental co-ordination and agreement on roles and responsibilities is key to the effective allocation of domestic and external resources. According to supporters, clearly allocated roles among ministries enhance communication and transparency, enabling donors to identify domestic priorities and to align financing behind these.

15. The results of the interviews revealed that national climate change strategies can provide an effective framework for the inter-ministerial allocation of roles. Although roles allocated to each ministry may vary across countries ${ }^{9}$, frequently allocated responsibilities mentioned by respondents are the 
establishment of a co-ordination mechanism, the formulation of a national climate change plan, and the monitoring of national emission reductions and the tracking of climate related expenditures ${ }^{10}$. According to recipients, a ministerial level decree can legally enforce the implementation of these roles, while a national council on climate change can foster co-operation and monitor progress for accountability among the responsible ministries and institutions. The importance of high-level leadership and engagement is a common lesson learned.

16. In many recipient countries at present, roles for overseeing climate change action and climate finance are not clearly assigned ${ }^{11}$. Where formal mechanisms for national co-ordination are often not yet established, the majority of donors and supporters working in country cite a lack of national co-ordination between the Environment, Finance and Planning Ministries. In such cases, a lack of clarity exists regarding who has the role to oversee climate change funding (UNDP, 2010). Interviewees revealed a range of barriers for why this may be the case, such as the time taken between the formulation, agreement and implementation of roles, and the formulation of plans in isolation and prior to the establishment of a coordination mechanism leading to a fragmentation of domestic climate action. Some recipient countries also highlighted a lack of political interest to engage in climate finance from the Ministry of Finance. Recipient countries reported that co-ordination challenges can sometimes be amplified by the fragmentation of donor financing and the lack of co-ordination across finance providers.

\section{In-country co-ordination among international climate finance providers}

17. The majority of the providers and recipients interviewed as well as supporters working in countries highlight that improving co-ordination at the country level across climate finance providers is an urgent and necessary action to increase the effectiveness of climate finance. According to recipient country views and experience, co-ordination across donor agencies in country can improve the effectiveness of resource allocation, by avoiding duplication and identifying synergies across initiatives. Recently, significant progress has been made in improving the share of co-ordinated, multi-donor programmes consistent with national development strategies in providing development finance (OECD, 2011b). For climate finance, the lack of co-ordination across providers remains a barrier, as found in five Asia-Pacific countries (UNDP, 2013a, section 2.ii.). However, despite the various barriers to pooling financing among finance providers (e.g. time to co-ordinate and build trust, competition for visibility, lack of understanding and network at ground level), there is an emerging body of evidence of harmonised donor activity and development co-operation in recipient countries. Box 1 provides examples. 


\section{Box 1. Mechanisms for development co-operation on climate finance in partner countries}

The Vietnam Support Programme to Respond to Climate Change (SPRCC) is a hybrid mechanism for pooling external climate finance and sharing knowledge on national climate policy. It is based on an innovative approach involving budget support to countries that decide to adopt a nationwide target of integrating the climate into their development strategies. It helps to meet the challenge of transforming countries' economic models by supporting the institutional capacity building and high-level inter-ministerial discussions on climate issues. The programme formerly known as the Six Banks initiative - was initiated by Agence Française de Développement (AFD) and Japan International Cooperation Agency (JICA), and is funded by a group of six donors operational in Vietnam ${ }^{1}$. Between 2009 and 2014, USD 873 million had been mobilised for the programme, all of which disbursed through the modality of direct budget support.

In addition to donors, the SPRCC also involves government ministries and representatives from civil society and the business sector. Progress on policy development is monitored twice a year through a full round consultation with the government. As a result, participating development co-operation practitioners reported that good co-ordination, a large country programme and well-defined national priorities on climate change are pre-conditions that enable effective climate finance in Vietnam.

The Kenyan Climate Change Co-ordination Group (CCCG) is a donor co-ordination mechanism that maps donor financed activities on climate change across Kenya. It is chaired by a permanent secretary and co-chaired by a donor on a rotating basis. Further, the group includes representatives from CSOs, the private sector, and local governments. As a result of biannual meetings with donors working in Kenya, domestic stakeholders and donors found it easier to understand each other's objectives in financing climate benefits in the country.

SIDS DOCK is a regional finance pooling and knowledge sharing mechanism, initiated by the Caribbean Community Climate Change Centre $(5 \mathrm{Cs})$ and the Secretariat of the Pacific Regional Environment Programme (SPREP). SIDS DOCK aims to secure sustainable energy through energy efficiency and renewable energy cooperation, and to mobilise financial and technical resources to catalyse low-carbon economic growth in Small Island Developing States (SIDS). To this end, it brings together stakeholders from the domestic government, private sector, and CSOs as well as bilateral and multilateral donors and actors from the global carbon markets.

1. AFD, AUSAID, CIDA, JICA, Korea Exim Bank and the World Bank

Source: Interviews by authors; Ministry of Natural Resources and Environment of Viet Nam, 2014

\section{Mainstream climate change considerations into development co-operation}

18. Climate finance providers and supporters see the integration of climate change into their broader mandate and operations to work on sustainable development as an effective way of linking climate finance with development. Indeed, many multilateral development banks, bilateral agencies and NGOs are now mandated to achieve climate change co-benefits while contributing to the core organisational mandates of poverty reduction and broader development outcomes. Some institutions go further still, for example, AFD mainstreams climate change mitigation into its operations by measuring the carbon footprint of its whole development finance portfolio (AFD, 2012) ${ }^{12}$.

\section{Align international climate finance with national strategies and priorities}

19. All recipients and some supporters and providers consider aligning climate finance behind priorities outlined in national climate change action plans as an important principle for effectiveness. Recipients and some supporters emphasised that external funding should match national priorities, rather than matching donors' own priorities, to maximise the impact of finance on the ground. Country specific priorities, needs and opportunities based on geographical and socio-economic conditions are best known to domestic stakeholders. Providers, whilst recognising the importance of aligning finance behind national 
priorities, also highlighted the need to consider global strategies and globally co-ordinated efforts in order to achieve effectiveness. For example, considering supra-national priorities was cited as necessary in demonstrating and advancing key low-carbon technologies along their learning curves and to successfully scale up approaches.

\section{E. Use of country systems to channel international climate finance}

20. Recipients, supporters and providers commonly regard the channelling of external finance using domestic systems, where appropriate, as effective in enhancing recipient country ownership. This was because when external finance is channelled through country systems, it is disbursed according to the recipient country's own planning, procurement and accounting systems, and avoids the creation of parallel processes and additional transaction costs. In the lead-up to Busan, the Manila Consensus on Public Financial Management recognised that using country systems can improve the effectiveness of climate finance. ${ }^{13}$ However, using country systems is not always appropriate, and evidence in developing countries reveals a mixture of donor and recipient preferences from budget support to designated climate funds.

21. The lack of accountability mechanisms was reported to limit the ability of donors to use domestic systems to channel support. Providers commented that budget support was often not a feasible modality to channel climate finance, the reason being that providers need to ensure that financing was being allocated to climate-related objectives and activities, and to monitor impacts. In contrast, finance channelled through the national budgetary processes is non-earmarked, and therefore its allocation is less transparent than finance disbursed through extra-budgetary channels ${ }^{14}$. According to recipient countries and supporters, applying a budget code to track climate related expenditures across all sectors can help to increase transparency and accountability of finance, but the majority of countries do not yet have a tracking system in place.

22. Providers are piloting innovative channels to increase the transparency and accountability of finance. One example is the establishment of a climate fund portal to operate within the budgetary system, as an experimental mechanism to manage climate finance inflows. The European Commission Global Climate Change Alliance (GCCA) champions channelling climate finance through a range of traditional and innovative modalities, such as budget support and sectoral support. Further, the Commission is experimenting with the use of off-budget national climate funds (NCFs) (GCCA, 2012). In some cases, providers and supporters are creating intermediary funds, designated to be replaced by domestically owned funds with time, or handed over to a domestic management authority once operational. In other cases, national funds have been created with the specific function of channelling sectoral climate finance, for example, the Indonesian Climate Change Trust Fund and the Indonesian forest fund for REDD+ (CFA and PWC, 2010). These experiences show that the success of using national climate funds is highly contextspecific, with many remaining uncertainties. However, as one provider pointed out, extra-budgetary NCFs may appear more efficient if seen as a stepping stone to more integrated finance.

23. In general, a wide range of views and practices were found across interviewees on NCFs, reflecting their exploratory stage. Whilst some view NCFs as inefficient "by default" in creating extrabudgetary processes, others see the value of off-budget funds that can transparently manage and monitor incoming climate finance. In countries with multiple existing funds, some recipients and supporters envisage a range of targeted funds effectively functioning as different channelling windows under the Green Climate Fund. Work is underway in exchanging a rapidly growing amount of country experience, notably in the Asia-Pacific region (UNDP, 2013b) ${ }^{15}$. 


\subsection{National transparency and accountability systems}

24. All recipients, providers and supporters agree that well-functioning national systems for tracking climate finance flows and for monitoring results can improve the effectiveness of international climate finance. Recipient countries recognise having both systems as a pre-condition for effective finance, while priorities of respondents varied; supporters mainly prioritised tracking flows, and providers were primarily interested in the monitoring of results and impact.

25. The main barriers recognised to establishing domestic systems for tracking and monitoring is that these systems are data and resource intensive. All three groups report that a lack of available data in recipient countries is a prominent barrier to tracking and monitoring finance in practice. The majority of recipients reported a lack of technical capacity to develop methodologies and systems to track climate finance as part of national systems, and expressed a demand for support from development co-operation providers. Countries pointed out that given the small number of officials working on climate finance in national ministries, just one staff member working on tracking and monitoring would be a large proportion of their human resources. Developed countries have committed to provide financial support to cover the full cost incurred by developing countries in complying with reporting duties towards the UNFCCC ${ }^{16}$.

26. There are good examples of where donors and supporters are helping to build statistical capacity in recipient countries via knowledge transfer and technical assistance to establish monitoring and evaluation systems at project level, as well as for national climate funds. For example, as part of national Climate Public Expenditure and Institutional Reviews (CPEIRs), a group of international organisations and research institutes are collaborating to assist countries in tracking climate finance across national budgets.

\section{F. Systems for tracking climate finance}

27. According to the majority of recipients and supporters and a minority of providers, national systems for identifying and tracking climate finance can enhance effectiveness, as tracking flows increases the transparency and accountability of finance. It was widely recognised that tracking flows to a certain level of granularity is also a pre-condition for monitoring outcomes and outputs. Both recipients and providers mentioned the importance of tracking so called "brown" or fossil fuel intensive investments in addition to climate finance, to effectively measure progress towards greenhouse gas emission reduction across their broader portfolio of investment activities.

28. Recipients and supporters have found that national tracking systems are useful tools to identify climate-related expenditures across budgets, to map current finance flows and to identify gaps where finance is needed. However, considering the resource intensity of establishing and operating tracking systems and the recent focus on defining and tracking flows in the context of the UNFCCC USD 100 billion commitment, providers of climate finance were sometimes of the view that an over-emphasis on tracking per se can itself be a barrier to effectiveness, redirecting scarce resources from achieving impact on the ground. On the other hand, recipient countries claimed that domestic systems tracking finance can be useful in verifying finance reported to the UNFCCC. Increasing mutual accountability this way could help to make progress towards reaching a political consensus on developed countries' progress towards the USD 100 billion commitment.

29. Countries reported that tracking climate-related expenditures across their budgets had encouraged donors to use budget support in channelling climate finance to a greater extent, by increasing the transparency of where the finance is going. To date, a few recipient countries have developed a national budget code for climate finance, often building on the methodology of the DAC Rio markers ${ }^{17}$ on climate 
change (Government of Kenya, 2012; Mulenga, 2012; Government of Zambia, 2011; Government of Nepal, 2012). In these countries, the Ministry of Finance tracks climate related expenditures across the budget, and occasionally through dedicated climate funds (e.g. Pilot Programme for Climate Resilience [PPCR]).

30. In Colombia, although existing monitoring systems for ODA allow for the tracking of concessional international climate finance, it is so far only based on donor provided information. The country is working on enhancing its monitoring system in order to include information from the recipient institutions, and on climate finance flows other than those reported as ODA. In Cambodia, the national ODA database allows for the tracking of aid to climate change, via a sector code and a thematic marker identifying projects with a climate change component ${ }^{18}$. In Malawi, the Rio markers methodology was applied to track adaptation related aid in the national Aid Management Platform (Weaver et al., 2012). These recent initiatives show that establishing national Measurement, Reporting and Verification (MRV) systems is a high priority of developing countries.

31. The majority of providers track climate-related finance in their portfolio using their own systems ${ }^{19}$. Recently, progress has been made to harmonise reporting methodologies used by bilateral and multilateral development banks, as well as national development banks in developed and developing countries. A common standard and system for tracking international climate finance between its providers and recipients is yet to be developed (Forstater and Rank, 2012).

\section{G. Systems for monitoring results and impact of climate finance}

32. Most respondents regard the development of a monitoring system and impact measurement framework as a pre-condition for effectively allocating finance. For example, among surveyed developing countries, the Ministry of Land, Natural Resource and Environmental Protection in Zambia monitors GHG emission reductions through the Zambia Environmental Management Agency (ZEMA). In particular, the vast majority of bilateral providers of finance were interested in monitoring results and progress towards achieving impacts on the ground. The prime reason cited for this was to demonstrate "value for money" of their international climate finance and for reasons of accountability towards their own taxpayers.

33. There are good examples of where donors and supporters are helping to build statistical capacity in recipient countries. For example, the Gesellschaft für Internationale Zusammenarbeit (GIZ) is working with the World Resource Institute (WRI) to provide technical assistance to establish impact monitoring and evaluation systems for adaptation programmes ${ }^{20}$ (GIZ, 2013). In Mexico, AFD is, beside its financial contributions to the national climate strategy (PECC - Programa Especial de Cambio Climatico), providing technical support to the implementation of the result-based national monitoring system of this cross-cutting policy (AFD 2012). In general, however, methodologies for result-based financing were reported to be newly developed or under development in developing countries, but also across donor agencies.

34. Providers and supporters are also in the process of establishing their own expertise, through systems to monitoring results to identify project impact and to measure benefits and trade-offs among different dimensions (e.g. environmental, social, economic, financial). For example, AFD, within its "climate and development action plan for 2012-2016", has established a systematic procedure to assess the carbon footprint of projects it finances in developing countries and the GHG impact is taken into account in AFD's decision making process. The United Kingdom has also developed a methodology to monitor the impact of GHG emission reductions of its International Climate Finance programme. The complexities and difficulties in developing these systems has been a significant challenge, in particular for measuring benefits of adaptation and impacts of strengthening domestic policy and institutional frameworks. 
Providers and supporters are developing better methodologies to broaden the evidence base and enable opportunities to be identified such that future finance can be allocated to projects and programmes with the highest returns.

\subsection{Capacity building and engagement}

\section{H. Access and readiness to finance from international climate funds}

35. While interviewees highlighted challenges in the use of country systems to channel international climate finance, dedicated climate funds are another important financing channel. Interviewees from all three groups mentioned that countries' ability to access and readiness to absorb finance from dedicated climate funds (e.g. the Adaptation Fund, Climate Investment Funds and Green Climate Fund) is an important element for the effective allocation, uptake and timely delivery of international climate finance. However, the lack of country capacity identified in many of the pre-conditions discussed in the preceding sections, together with the large number of climate funds with separate procedural requirements and eligibility criteria is considered to be a barrier to recipient countries in accessing finance from these funds and thus to the effective distribution of funding.

\section{Access to international climate funds}

36. Some recipients, as well as supporters and providers mentioned the importance of effective access to international climate funds, and within that, direct access being a preferred modality. Direct access increases country ownership and helps to avoid high transactional costs of accessing finance through implementing agencies. However, due to the complex funding arrangements of international and regional climate funds, interviewees outlined that accessing international climate finance is often a resource and time-consuming process stretching beyond the length of election cycles, which can be an additional challenging aspect to elected governments.

37. Providers and supporters are working together to help countries access international climate funds, and at the same time, considering using country systems as a direct way to improve access to international climate finance. Finance providers are assisting recipient countries to blend finance from international climate funds with other development finance. As the accreditation of a National Implementing Entity (NIE) for direct access to the Adaptation Fund is a resource intensive procedure, recipient, supporters and providers have worked together to build capacity to accelerate access to the Fund. At the same time, they are also raising awareness that finance available from international climate funds is so far relatively limited, but designed to play a catalytic role in mobilising additional finance.

\section{Capacity and readiness to receive climate finance}

38. The lack of country capacity and readiness to absorb financing for low-carbon development was cited by many providers, supporters and some recipients as a prevailing barrier to the effective allocation of internationally available finance. Country readiness to usefully direct climate finance depends on the availability of programmes and maturity of project pipelines in line with national strategies, project/programme investment criteria, national co-ordination as well as enabling environments, policy and legal frameworks and accountability systems. A series of country barrier studies are underway or have been undertaken in Latin America and the Caribbean (for example, see Government of El Salvador, 2012) to identify country specific capacity gaps, while supporters and providers are assisting countries in developing project pipelines. Provider agencies are also coupling finance with technical assistance to increase in-country capacity to access and direct climate finance. 


\section{Engagement with civil society, local government and the private sector}

39. The majority of interviewees from all groups engage with local governments, civil society organisations (CSOs) and the private sector, and regard engagement as an effective practice ${ }^{21}$. They explained that working with local government and NGOs can help to ensure that finance is targeted to the needs of the poor or to those who are the most vulnerable to climate change. In parallel, engaging the private sector and enhancing public-private partnerships can create an enabling environment for private sector investment.

40. Recipient country national governments are of the view that engaging NGOs, local government and the private sector in the formulation of the national action plans and co-ordination mechanisms, as well as the tracking and monitoring of climate change activities and finance, are effective ways for engagement. However, some respondents reported challenges due to a lack of experience in co-ordinating with subnational governments and the private sector. Supporters are engaging with a wide range of stakeholders, and this can foster knowledge exchange and learning on climate compatible development practices. For example, some are pursuing engagement through the networks of regional NGOs in Asia, Africa and LatinAmerica, conducting country case studies on climate finance through national research centres, and working with local governments on capacity building and tracking.

41. Respondents from all groups interviewed are committed to involving the private sector as an effective practice for climate finance. Donor agencies in particular are actively seeking ways to work with the private sector to mobilise investments. For example, donor agencies are partnering with private sector financing institutions to demonstrate the commercial viability of climate-smart technologies, and mobilising investments via innovative financial instruments, such as loan guarantees. In recipient countries, donors have participated in domestic pooling mechanisms to blend public with private finance, and are disbursing commercial loans, equity and finance for tax incentives. Looking forward, the expected level of the private sector's engagement in the mobilisation and delivery of international climate finance is likely to increase.

\section{KEY FINDINGS}

42. Qualitative data from interviews with international climate finance practitioners and experts suggest a common understanding on the key pre-conditions of effectiveness of international climate finance, many of which are based on the principles of aid effectiveness. These are: 1) integrating climate change into development planning and policies; 2) in-country co-ordination across ministries and providers; 3) domestic accountability systems for climate finance; 4) country readiness and access to international climate funds; and 5) engagement with civil society, local government and the private sector. These insights are in line with the findings of research elsewhere (such as Bird et al., 2013; Nakhooda, 2013) and the objectives of on-going activities aiming to improve the effectiveness of international climate finance, such as CPEIRs and barrier studies (Bird et al. 2012).

43. Interviewees agreed on the overarching need to strengthen MRV systems for climate finance, but differences in views were found regarding providers' and recipients' relative priorities over the tracking of finance flows versus the monitoring of results. On the use of country systems and aligning finance behind 
national priorities, providers acknowledge these as good practices, but emphasise the need to balance between these practices with their own strategic as well as global priorities, while the optimal design and use of national climate funds remains under discussion. The emphasis on and appropriateness of preconditions were also found to be context specific, depending on the source and objective of finance.

44. Many of the pre-conditions and elements to enable effectiveness identified through this research are considered to be inter-linked, and may require simultaneous and sequential action (for example, integrating climate change into national development plans can help to define national priorities, before donors can then align behind these). In this respect, improving effectiveness may require co-ordinated and complementary efforts from all stakeholder groups, recognising too that there may be effectiveness tradeoffs between the urgency to scale-up climate finance in the near term and the need to build country capacity and readiness.

45. Establishing domestic policy, institutional and accountability frameworks for climate finance takes time and needs to be country-led. In the meantime, bringing different communities and sectors together to share lessons learned and to build a consensus on how to strengthen domestic institutions for managing climate finance and how to improve the international architecture of climate finance will be a key step towards the effective allocation and delivery of resources. Development co-operation can play an important role in building trust, facilitating knowledge sharing and accelerating learning from experience across countries and regions, as well as the development, climate change and finance communities.

46. The findings of this report provide initial insights on the pre-conditions enabling effective climate finance in the context of development co-operation. Going forward, there may be a need for new considerations and additional pre-conditions or principles that go beyond the insights from this research. In particular, the increasing role of private climate finance and South-South and triangular co-operation in scaling up climate finance to meet global needs, as well as specific objectives of international climate funds may require a broader set of pre-conditions for effectiveness. Emerging lessons on mobilising climate finance by innovative financing mechanisms and national and international climate funds could complement and refine these insights. Further research may also be required to improve understanding and measurement of the effectiveness of results and impact of international climate finance. However, the bigger challenge will be to apply the lessons learned on effectiveness at the practitioners' level, in designing new financing mechanisms and allocation rules. The Green Climate Fund is showing promise in terms of incorporating these aspects into its project selection criteria. 


\section{ANNEX: LIST OF INTERVIEWEES}

\section{Providers of climate finance}

1. Marcia Levaggi, Adaptation Fund

2. Preety Bhandari, Asian Development Bank (ADB)

3. Sophie de Coninck, European Union, Global Climate Change Alliance (GCCA)

4. Pierre Forestier, France, Agence Française de Développement (AFD)

5. RuthaAbraha and Regina Bernhard, Germany, Deutsche Gesellschaft für Internationale Zusammenarbeit (GIZ)

6. Joon-HoMaeng, South Korea, Export-Import Bank (Eximbank)

7. Malcolm Smart and Samuel Balch, United Kingdom, Department for International Development (DfID) and Department for Energy and Climate Change (DECC)

8. Peter King, United States, Agency for International Development (USAID) ADAPT AsiaPacific

9. Adrian Fozzard and Philippe Ambrosi, World Bank

\section{Recipients of climate finance}

10. Isabel Cavelier Adarve, Colombia, Ministry of External Affairs (Cancilleria)

11. Karoline Pacheco and Ana Galeano, Honduras, Ministry of Planning and External Cooperation (SEPLAN)

12. Syamsidar Thamrin, Indonesia, National Development Planning Agency (Bappenas)

13. Fatuma Hussein, Kenya, Ministry of Environment and Mineral Resources - Head of National Climate Change Secretariat

14. Gaylor Montmasson-Clair, South Africa, Trade and Industrial Policy Strategies (TIPS)

15. Samuel Marwa and Stephen Godlove, Tanzania, Ministry of Finance

16. Charles Mulenga, Zambia, Institute of Environmental Management

17. David Kaluba, Zambia, Ministry of Finance - Pilot Program for Climate Resilience (PPCR) focal point 


\section{Supporters of climate finance}

18. Ari Huhtala, Climate and Development Knowledge Network (CDKN)

19. Barbara Buchner, Climate Policy Initiative (CPI), Venice Office

20. Britta Hortsmann, Deutsches Institut für Entwicklungspolitik (DIE)

21. Neil Bird, Overseas Development Institute (ODI)

22. Scott Hook, Pacific Islands Forum Secretariat

23. Thomas Beloe, United Nations Development Programme (UNDP), Asia-Pacific Regional Centre

24. Dao Xuan Lai and Johan Kieft, United Nations Development Programme (UNDP), Vietnam Country Office

25. Angus Mackay, United Nations Industrial Development Organization (UNIDO)

26. Louise Brown, World Resource Institute (WRI) 


\section{BIBLIOGRAPHY}

AFD (2012), Reconciling Development and the Fight Against Climate Change, Action Plan 2012-2016, AFD, Paris.

Bird, N. et al. (2013), Measuring the effectiveness of public climate finance delivery at the national level, ODI, London.

Bird, N. et al. (2012), Understanding climate change finance flows and effectiveness - mapping of recent initiatives, ODI, London.

Brown, J. et al. (2011), Improving the Effectiveness of Climate Finance: A Survey of Leveraging Methodologies, CPI, Venice.

Buchner, B. et al. (2012), Public Climate Finance: A Survey of Systems to Monitor and Evaluate Climate Finance Effectiveness, CPI, Venice.

Busan Partnership for Effective Development Co-operation (2011), Fourth High-level Forum on Aid Effectiveness, Busan, Republic of Korea.

CFA and PwC (2010), Report for the Conservation Finance Alliance: National REDD+ funding frameworks and achieving REDD+ readiness - findings from consultation.

Clapp, C., Briner, G., Karousakis, K. (2012), Low-Emission Development Strategies (LEDS): Technical, Institutional and Policy Lessons, OECD, Paris.

CPI (2014), Global Landscape of Climate Finance 2014, CPI, Venice.

Ellis, J., R. Caruso and S. Ockenden (2013), "Exploring Climate Finance Effectiveness", OECD/IEA Climate Change Expert Group Papers, No. 2013/04, OECD Publishing, Paris.

Forstater, M. and R. Rank (2012), Towards Climate Finance Transparency, Publish What You Fund and Aid Info.

GCCA (2012), Paving the Way for Climate Compatible Development: Experiences from the Global Climate Change Alliance. GCCA, European Commission, Brussels.

GIZ (2013), Ready for Climate Finance: GIZ's Approach to Making Climate Finance Work: Building on climate expertise and good financial governance, GIZ, Germany.

Government of El Salvador (2012), How to Overcome the Barriers to Successful Climate Finance, San Salvador / Washington, DC.

Government of Kenya (2012), National Climate Change Action Plan 2013-2017, Government of Kenya, Nairobi. 
Government of Nepal (2012), Climate Change Budget Code Criteria and Method: Documenting the national process of arriving at multi-sectoral consensus, Government of Nepal, National Planning Commission, Kathmandu.

Government of Zambia (2011), Sixth National Development Plan 2011-2015: Sustained Economic Growth and Poverty Reduction, Government of Zambia

Manila Consensus on Public Financial Management (2011), Partnering to Strengthen Public Financial Management for Effective States, Manila, Philippines.

Ministry of Natural Resources and Environment of Viet Nam (2014), Support Program to Respond to Climate Change (SP-RCC) in Viet Nam, Ministry of Natural Resources and Environment, Ha Noi.

Mulenga, C. (2012), Tracking of Public and Private Climate Finance Inflows to Zambia, Climate Change Expert Group (CCXG), Paris.

Nakhooda, S. (2013), "The effectiveness of international climate finance", Working Paper 371, ODI, London.

OECD (2016), Climate Finance in 2013-14 and the USD 100 billion Goal: A Report by the OECD in Collaboration with Climate Policy Initiative, OECD Publishing, Paris, http://dx.doi.org/10.1787/9789264249424-en.

OECD DAC (2015), OECD DAC Statistics on Climate- and Environment-related Development Finance, http://oe.cd/RioMarkers.

OECD (2014), Towards Green Growth in Southeast Asia, OECD Green Growth Studies, OECD Publishing, Paris, http://dx.doi.org/10.1787/9789264224100-en.

OECD (2013), Putting Green Growth at the Heart of Development, OECD Green Growth Studies, OECD Publishing, Paris, http://dx.doi.org/10.1787/9789264181144-en.

OECD (2011a), Handbook on the OECD-DAC Climate Markers, OECD, Paris, https://www.oecd.org/dac/stats/48785310.pdf.

OECD (2011b), Aid Effectiveness 2005-2010: Progress in Implementing the Paris Declaration, OECD, Paris, http://www.oecd.org/development/effectiveness/48734301.pdf.

OECD (2010a), Glossary of Key Terms in Evaluation and Results Based Management, OECD, Paris, http://www.oecd.org/development/peer-reviews/2754804.pdf.

OECD (2010b), Realising the Potential: Making the Most of Climate Change Finance in Africa, OECD, Paris, http://www.oecd.org/dac/environment-development/48597031.pdf.

OECD (2006), Good Practices in the National Sustainable Development Strategies of OECD Countries, OECD, Paris, http://www.oecd.org/greengrowth/36655769.pdf.

UNDP (2013a), Climate Public Expenditure and Institutional Reviews (CPEIRs) in the Asia-Pacific Region: What have we learned? UNDP, Bangkok. 
UNDP (2013b), National Climate Funds: Learning from the experience of Asia-Pacific countries, UNDP, Bangkok.

UNDP (2010), Realising Development Effectiveness: Making the Most of Climate Change Finance in Asia and the Pacific, UNDP, Bangkok.

UNFCCC (2015), Paris Agreement, Decision CP.21, UNFCCC, Bonn.

Weaver, C., Baker, J., Peratsakis, C. (2012), "Tracking Climate Adaptation Aid: Methodology", Climate Change and African Political Stability, Research Brief No.5.

\section{NOTES}

Net disbursements from the Development Assistance Committee (DAC) of the OECD, Source: OECD DAC CRS database.

Third International Conference on Financing for Development, 13-16 July 2015, Addis Ababa, Ethiopia.

The research behind this paper does not address the debate around what is "new and additional" in climate finance, leaving the interpretation of the term "international climate finance" to the interviewees.

Formally acknowledged in the Paris Declaration (2005) and the Accra Agenda for Action (2008).

See Paragraph 34 of the Busan Partnership for Effective Development Co-operation.

Nationally Appropriate Mitigation Action (NAMA) and National Adaptation Programmes of Action (NAPA).

The Low-Emission Development Strategy and the Reduced Emissions from Deforestation and Forest Degradation (REDD+), led by the Ministry of Environment and Sustainable Development, the National Adaptation Plan led by the National Department of Planning, and the Strategy for the Fiscal Protection of the State Against Natural Hazards led by the Ministry of Finance. Source: National Institutional Strategy for Climate Change.

These are 1) geothermal power generation; 2) distributed clean energy solutions; 3) improved water resources management, 4) restoration of forests; 5) climate-smart agriculture and agroforestry; 6) infrastructure.

For example, in Zambia, the Ministry of Finance is responsible for tracking climate related expenditures across the budget, while in Colombia, the Ministry of Finance leads the sectoral strategy on natural disaster management, among other roles.

For example, in Zambia, the Ministry of Finance is responsible for tracking climate related expenditures across the budget, while in Colombia the Ministry of Finance leads the National Strategy for the Fiscal financial Protection of the State Against Natural Hazards. 
A mitigation project is defined as "a development project whose emission reductions in greenhouse gas (GHG) emissions that it generates are greater than emissions it produces during its lifetime".

See proposal III. of the Consensus.

In other cases when there are no existing donor programmes for budget support, providers did not find it practical to set up a pilot programme to channel climate finance, as climate finance it is by default crosssectoral and therefore difficult to monitor.

See for example, ADAPT Asia-Pacific 2nd annual meeting.

See UNFCCC Article 4.3 and Article 12.1.

See OECD (2011a).

See Cambodian ODA database accessible at http://cdc.khmer.biz/.

For example, by reporting towards the DAC Rio markers, the joint MDB methodology or the IDFC methodology for tracking mitigation and adaptation-related development finance.

Supreme Audit Institutions (SAIs) are important institutions in a national accountability framework. Although most of SAIs do not yet have the capacity and expertise to audit climate finance, it is within their mandate to audit public climate finance. In this respect, GIZ is providing support to SAIs in developing countries to strengthen their mandates.

An exception is the direct channelling of external funding to local and non-governmental stakeholders, which was viewed by some as ineffective as it creates parallel processes. 


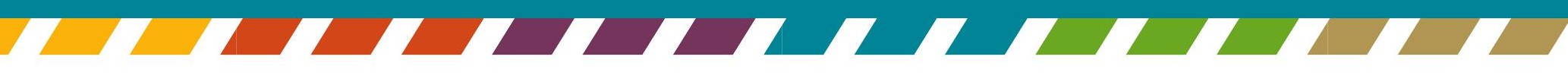

